\title{
Response of onion (Allium cepa L.) to different levels of NPK and FYM under arid condition of Rajasthan
}

\author{
PRIYANKABAIRAGI, S.R. YADAV AND DINESH KUMAR
}

Received : 04.10.2014; Revised : 11.04.2015; Accepted : 20.04.2015

MEMBERS OF RESEARCH FORUM:

Corresponding author : DINESH KUMAR, Department of Soil Science and Agricultural Chemistry, College of Agriculture, BIKANER (RAJASTHAN) INDIA Email: dkrachiata@gmail.com
Co-authors :

PRIYANKA BAIRAGI AND S.R. YADAV, Department of Soil Science and Agricultural Chemistry, College of Agriculture, BIKANER (RAJASTHAN) INDIA

\section{Summary}

A field experiment was conducted at Niche area of Excellence Farm, Swami Keshwanand Rajasthan Agricultural University, Bikaner during Rabi season, 2012-13. The experiment was laid out in split plot design with four replications consisted of four levels NPK fertilizers through drip irrigation (control, 75, 100 and 125\% recommended dose of NPK fertilizer) in main plots and four levels of FYM (control, 10, 20 and $30 \mathrm{tha}^{-1}$ ) in sub plots. The soil of experimental site was loamy sand in texture containing $78.85,18.80$ and $180.00 \mathrm{~kg} \mathrm{ha}^{-1}$ available $\mathrm{N}, \mathrm{P}$ and $\mathrm{K}$, respectively in $0-15 \mathrm{~cm}$ soil depth with $\mathrm{pH} 8.68$, EC $0.28 \mathrm{dS} \mathrm{m}^{-1}$ and OC 0.15 per cent. A significant increase of diameter of bulb at equatorial and polar was recorded with application of 100per cent recommended dose of NPK fertilizer over control and 75per cent recommended dose of NPK fertilizer through drip irrigation. Maximum diameter of bulb of onion at equatorial and polar was recorded with addition of $30 \mathrm{t} \mathrm{FYM} \mathrm{ha}^{-1}$ as compared to control, 10 and $20 \mathrm{t} \mathrm{FYM} \mathrm{ha}^{-1}$. Significant increase of 18.33 and 7.51 per cent in fruit weight of onion was recorded with the application of 100 per cent recommended dose as compared to control and 75 per cent recommended dose through drip irrigation, respectively. Incorporation of FYM 10, 20 and $30 \mathrm{tha}^{-1}$ registered an increase in bulb weight of onion in order of 10.55, 18.73 and 26.06 per cent, respectively over no incorporation of FYM. A significant increase in the bulb and stover yield of onion with application of 100 per cent recommended dose of NPK fertilizer over control and 75 per cent recommended dose of NPK fertilizer through drip irrigation. Significant increase of 55.35 and 13.56 per cent in bulb yield of onion was recorded with the application of 100 per cent recommended dose as compared to control and 75 per cent recommended dose through drip irrigation. Bulb yield of onion increased significantly with addition of FYM $30 \mathrm{t} \mathrm{ha}^{-1}$. Incorporation of FYM 10, 20 and $30 \mathrm{t} \mathrm{ha}^{-1}$ registered an increase in bulb yield of onion in order of 26.71, 47.33 and 63.74 per cent, respectively over no incorporation of FYM. Combination of 100 per cent recommended dose of NPK fertilizer along with $30 \mathrm{t} \mathrm{FYM} \mathrm{ha}^{-1}$ also resulted in significantly increased bulb yield of onion over other combinations of fertilizer levels and FYM levels except 125per cent recommended dose of NPK fertilizer along with $30 \mathrm{t} \mathrm{FYM} \mathrm{ha-1.}$

Key words : Onion, FYM, NPK, Fertigation, Growth, Yield

How to cite this article : Bairagi, Priyanka, Yadav, S.R. and Kumar, Dinesh (2015). Response of onion (Allium cepa L.) to different levels of NPK and FYM under arid condition of Rajasthan. Asian J. Soil Sci., 10(1) : 42-46. 